\title{
SAFETY AND QUALITY CONTROL RAW MEAT AND MEAT PRODUCTS IN RUSSIA
}

\author{
К ВОПРОСУ БЕЗОПАСНОСТИ И КОНТРОЛЯ КАЧЕСТВА МЯСНОГО СЫРЬЯ И \\ МЯСНЫХ ПРОДУКТОВ В РОССИИ
}

T. Kozlova, Candidate of Technical Sciences

Т.А. Козлова, кандидат технических наук

Orel State Agrarian University, Orel City, Russia

Орловский государственный аграрный университет, г. Орёл, Россия

Phone: +7 (909) 228-17-63, E-mail: kozlova tatyana@inbox.ru

Received May 7, 2012

\begin{abstract}
The article discusses need for quality control of raw meat and meat products, raw materials determine the composition of meat products. Research has established the facts of falsification, when the meat products that contain herbal ingredients, the documents that declared their absence.
\end{abstract}

\section{АННОТАЦИЯ}

В статье рассматривается вопрос о необходимости контроля качества мясного сырья и мясных продуктов, определения сырьевого состава мясопродуктов. Исследованиями установлены факты фальсификации, когда на мясные продукты, содержащие растительные ингредиенты, представляются документы, в которых декларируется их отсутствие.

\section{KEY WORDS}

Meat products; Meat; Products; Meat industry; Quality.

КЛЮЧЕВЫЕ СЛОВА

Мясные продукты;; Мясо; Продукты; Мясная индустрия; Качество.

Актуальность проблемы производства пищевых продуктов из животного сырья определяется стратегией формирования здорового образа жизни и рационального питания населения страны в соответствии с концепцией государственной политики в этой области.

Формирование в России рыночных условий, развитие общества, увеличение объема производства продовольственных товаров и свободной торговли, в том числе мясным сырьем и мясными продуктами, предопределяет возможность различной их фальсификации, как по структуре, так и по видовой принадлежности сырьевых составляющих. По экономическим соображениям чаще всего фальсифицируют малоценное и недоброкачественное мясное сырье, готовые продукты второго и третьего сортов, реализуя их как продукцию высокого качества. Фальсификация продовольственных товаров с правовой точки зрения представляет разновидность именно экономического мошенничества и заключается, главным образом, в действиях, направленных на обман покупателя за счет подделки продуктов с целью наживы.

Согласно статистическим данным Роспотребнадзора, на рынках и в торговых предприятиях страны в последние годы заметно увеличился сбыт фальсифицированных продовольственных и, прежде всего, мясных товаров как отечественного, так и импортного производства. При этом в большинстве случаев производители и продавцы фальсифицированной продукции не несут, какой-либо ответственности и остаются безнаказанными, так как контролирующие органы не могут определить подмену мяса одних видов животных мясом других, менее ценных видов, или замену на растительные компоненты. 
В настоящее время особенно остро стоит вопрос о необходимости более достоверного определения, как видовой принадлежности, так и состава мясных фаршированных продуктов. Это связано с тем, что фальсификация мяса может привести к изменениям не только потребительских свойств готовых изделий, но и создать опасность для здоровья потребителей.

Наибольшее беспокойство у ветеринарных специалистов вызывают возможные подмены мясного сырья в продуктах мясом животных, пораженных прионами или вирусами, создающими большой риск в эпизоотическом и эпидемическом отношениях, а также мясом, импорт которого в нашу страну по какимлибо причинам запрещен.

Кроме того, фальсификация видовой принадлежности мясного сырья и многокомпонентных мясных может нанести большой моральный вред той категории потребителей национальные или религиозные воззрения которых не позволяют потреблять мясо отдельных видов животных и птиц, о чем они могут узнать, потребовав проведения дополнительного лабораторного контроля.

Хочется особо отметить, что кроме случаев замены высококачественного мясного сырья на сырье более низкого качества, в последнее время участились случаи замены мясного сырья на растительные белоксодержащие компоненты без указания этого на этикетке продукта. Так в настоящее время до $80 \%$ мясных продуктов, заявляемых как произведенные в соответствии с ГОСТом, являются фальсифицированными за счет введения в их состав, не предусмотренных нормативной рецептурой растительных добавок: до $50 \%$ - белковых (соевые белковые продукты) и до 60\% - углеводных (крахмал, каррагинан, различные камеди) [6].

На стадии разработки и внедрения находятся продукты из генетически модифицированных источников (ГМИ) с повышенной пищевой ценностью, обладающие длительным сроком хранения, улучшенной органолептикой, отсутствием аллергенов и другими свойствами [1]. Рассматривая использование генно-инженерных технологий в сфере производства мясных продуктов, как исключительно перспективное направление, следует учитывать потенциальную возможность непреднамеренного или преднамеренного создания продуктов из ГМО, способных оказать негативное влияние на организм человека в условиях неконтролируемой генно-инженерной деятельности. Это обуславливает необходимость обеспечения многоуровневого контроля за мясной продукцией, имеющей генноинженерно-модифицированные аналоги, включая госсанэпиднадзор и производственный контроль с обязательным осуществлением лабораторных исследований. Кроме того, исходя из мировой практики по контролю продукции за соблюдением научно обоснованных рецептур и определению сырьевого состава готовых мясных продуктов на соответствие требованиям нормативной документации (НД), нередко отмечаются нарушения данных требований.

Все это свидетельствует о необходимости идентификации состава поставляемой на рынок мясной продукции. В связи с этим, мониторинговые исследования мясных изделий на предмет выявления фальсификации сырьевого состава и наличие генетически модифицированных объектов более чем актуальны.

Согласно испытаниям, проведенным в МГУ прикладной биотехнологии, генетически модифицированные соевые продукты по своим потребительским свойствам мало отличаются от традиционных аналогов [4]. Однако, поскольку безопасность трансгенных продуктов не установлена, у потребителя должен быть выбор между нативными продуктами и продуктами, полученными с помощью биотехнологических методов.

Информация о трансгенных компонентах в составе пищевых продуктов должна быть максимально открытой для потребителя. Между тем практика показывает, что производители не всегда маркируют свою продукцию должным образом, часто не дают информации для потребителя об использовании в производстве продукта ГМО [8].

В связи с поступлением на потребительский рынок большого объема и разнообразного ассортимента отечественных и импортных мясных продуктов требуется тщательный и быстрый контроль их качества. Для решения некоторых аспектов проблемы качества, безопасности и подтверждения соответствия продукции возникает необходимость использования эффективных методов и тест-систем, отвечающих требованиям международных стандартов. 
Наиболее перспективными являются иммунологические методы, методы с использованием полимеразной цепной реакции (ПЦР), методы иммуноферментного анализа, а также гистологические методы идентификации сырьевого состава мясопродуктов.

Иммуноферментные методы успешно используются для идентификации соевых производных в пищевых продуктах. В то же время их существенным недостатком является невозможность определения технологической формы соевых компонентов (концентрата, изолированного белка, муки, текстурата), а также его количества в продукте. Особенно это имеет значение в случае использования смесей. Кроме того, важно отметить, что на применение иммуноферментных методов в России не разработано необходимых нормативных документов государственного уровня, что значительно затрудняет их широкое использование.

В международной практике для контроля качества и исключения возможности фальсификации мясных продуктов применяют гистологические методы идентификации состава. В последние годы сотрудники лаборатории микроструктурного анализа мясных продуктов ВНИИ мясной промышленности им. В.М. Горбатова (ВНИИМП) провели углубленные исследования по определению структурных особенностей различных компонентов мясных продуктов с применением современной светооптической микроскопии и компьютерных анализаторов изображения [5].

Одним из результатов этой работы явилась разработка ГОСТ Р 51604 «Мясо и мясные продукты. Метод гистологической идентификации состава» и ГОСТ Р 52480 «Мясо и мясные продукты. Ускоренный метод определения сырьевого состава». Накопленные данные о микроструктурных особенностях растительных компонентов разной химической природы, а также их изменениях в ходе технологических воздействий позволяют провести идентификацию состава использованных в мясных продуктах растительных добавок. При этом возможно установление не только химической природы добавки, но и примененной технологической формы.

В настоящий момент метод проведения идентификации растительных добавок в мясных продуктах, в том числе с использованием гистологического анализа, регламентирован частично в рамках ГОСТ Р 51604 и ГОСТ Р 52480. В то же время данные нормативные документы регламентируют исключительно методические подходы к отбору и обработке материала для исследования. При этом анализ получаемых данных и идентификация конкретных растительных добавок углеводной и белковой природы, широко используемых в переработке мяса, остаются за рамками официальных документов.

В связи с участившимися случаями несоответствия мясных продуктов нормативной документации ВНИИМПом совместно с компанией ООО «Биоком» (г. Москва) был разработан и утвержден в 2007 г. ГОСТ Р 527232007 «Продукты пищевые и корма. Экспрессметод определения сырьевого состава (молекулярный)» [2], который разрабатывался для выявления фальсификации сырьевого состава пищевой продукции методом полимеразной цепной реакции. В мировой практике методы, основанные на ПЦР, зарекомендовали себя как специфические и чувствительные $[3,5]$.

Высокая специфичность указанного метода обусловлена тем, что в исследуемом образце выявляется уникальный фрагмент ДНК, характерный только для данного вида сельскохозяйственных животных или растений. Специфичность задается нуклеотидной последовательностью праймеров, что исключает возможность получения ложных результатов. Но, к сожалению, на полученные результаты влияют степень фрагментации нуклеиновой кислоты, наличие низкомолекулярных примесей, колебание $\mathrm{pH}$ и температуры. Данный метод неприемлем в тех случаях, когда в определяемом веществе не сохраняется нуклеотидный материал, как, например, в случае с изолированным соевым белком.

Метод ПЦР можно применять не только для обнаружения растительных белковых добавок в составе мясных продуктов, но и для идентификации ГМИ в них, что повышает его востребованность. В РФ утверждены и действуют два национальных стандарта на методы идентификации ГМИ, основанные на применении ПЦР: ГОСТ Р 52173-2003 «Сырье и продукты пищевые. Метод идентификации ГМИ растительного происхождения» и ГОСТ Р 52174-2003 «Биологическая безопасность. Сырье и продукты пищевые. Метод идентификации ГМИ растительного происхождения с применением биологического микрочипа». 
В соответствии с вышеизложенным, в ПЦР-лаборатории Инновационного научно исследовательского испытательного центра (ИНИИЦ) Орловского государственного аграрного университета (№ POCC.RU. 0001.21ПЦ26 от 19.02.2008 г.; лицензия №21ПЦ26) проводились испытания мясных изделий, закупленных в крупных торговых точках города Орла.

Исследования проводились согласно ГОСТ Р 52723 - 2007 «Продукты пищевые и корма. Экспресс-метод определения сырьевого состава (молекулярный)».

Полимеразную цепную реакцию (ПЦР/PCR) в реальном времени (RT) проводили с использованием амплификатора с оптической частью IQ-5 (BIO-RAD) и электрофоретической детекцией в агарозном геле (МУК 4.2.2305-07). При помощи данной системы регистрация появления и накопления ампликонов происходит по флуоресцентному сигналу в закрытых пробирках в процессе амплификации в закрытых пробирках в процессе амплификации. Это исключает контакт продуктов ПЦР с окружающей средой, тем самым, снижая вероятность контаминации лаборатории ампликонами, значительно упрощает стадию детекции, сокращает время анализа, повышает надежность регистрации результатов.

Для выделения ДНК из клинического материала использовали набор «Проба ЦТАБ»

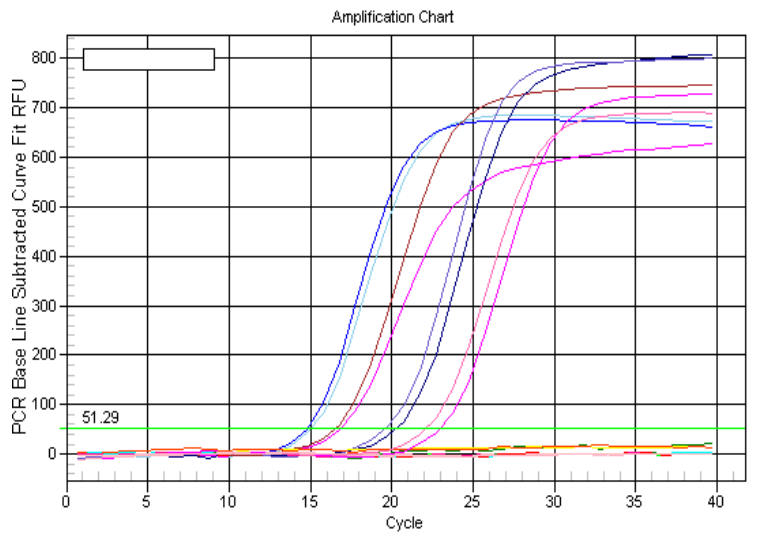

a (ручной метод) и InviMAG_Virus_KFml на автоматизированной станции King Fischer.

Для определения генно-инженерномодифицированных организмов (ГМО) в исследуемых образцах использовали тестсистему «Квантум-П-соя» (ДНК-технологии) со специальными стандартами ДНК с известной концентрацией в формате ПЦР с флуоресцентной детекцией в режиме «реального времени» (RT).

Анализ с использованием тест-системы «Квантум-П-соя» заключался в определении наличия ДНК сои и рекомбинантной ДНК промотора $35 \mathrm{~S}$ в исследуемых образцах. Для флуоресцентной детекции продуктов ПЦР в реальном времени были использованы флуорофоры FAM (FAM - 490) - специфичный продукт (рекомбинантная ДНК промотора 35S), HEX (HEX - 530) - ген сои (рис. 1).

Наличие четких линий отрицательного «К-» и положительных «К+» контрольных образцов подтверждают отсутствие контаминации и чистоту постановки эксперимента. Присутствие уровня пороговой флуоресценции (thresphold) или линии СТ позволяет утверждать о начале детекции экспоненциальной фазы амплификации, о наличии которой наиболее точно отвечает репортерная флуоресценция. Обычно оптимальными являются пороговые уровни порядка 0,05-0,1 единиц флуоресценции, что и наблюдается в данном опыте (CT=51,29 и 51,28).

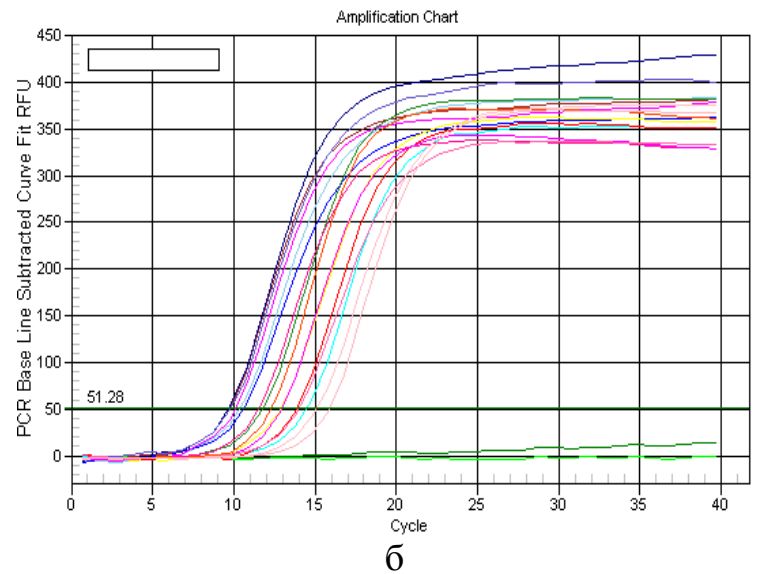

Рисунок 1 - Флуоресцентная детекция при проведении ПЦР в режиме реального времени: а) FAM-флуорофор; б) НЕХ-флуорофор

Кривые флуоресценции позволяют утверждать, что все экспериментальные образцы содержат ДНК сои, что не отражено на упаковке продукта.
Метод флуоресцентной детекции представляет собой регистрацию флуоресцентного сигнала, уровень которого пропорционален содержанию ДНК в реакционной смеси, при 
этом детекцию осуществляют непосредственно во время амплификации - в режиме реального времени (RT).

Количественный анализ наличия/отсутствия рекомбинантной ДНК промотора $35 \mathrm{~S}$ в исследуемых образцах показал, что найденный видоспецифичный ген содержится в количествах, не превышающих установленное Постановлением Главного Государственного врача РФ № 42 от 25.06.2007 г.
Для определения видовой принадлежности тканей жвачных животных, кур и свиней методом ПЦР с электрофоретической детекцией продуктов амплификации в агарозном геле использовали тест-системы «БИГ» и «ЧИС» (ФГУН ЦНИИЭ Роспотребнадзора).

Анализ с использованием тест-систем «БИГ» и «ЧИС» (ФГУН ЦНИИЭ Роспотребнадзора) показал фальсификацию качественного состава мясных продуктов (рис. 2).

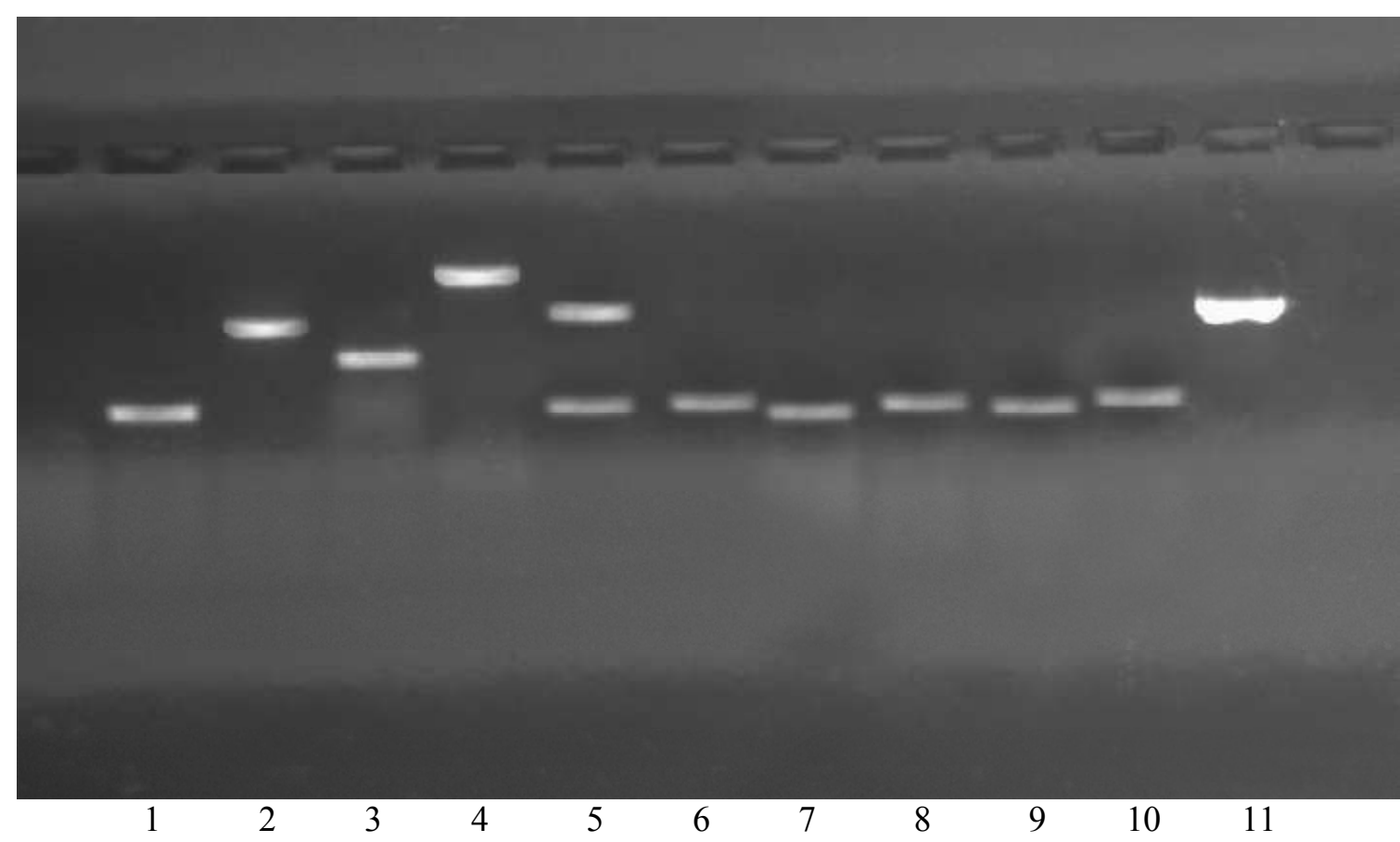

Рисунок 2 - Электрофореграмма фрагментов видоспецифичной ДНК:

1 - ДНК свиньи; 2 - ДНК кур; 3 - ДНК КРС; 4 - ДНК МРС; 5 - Колбаса Докторская без сои; 6 - Колбаса Докторская Русская; 7 - Колбаса Докторская Стародворская; 8 - Колбаса Докторская в натуральной оболочке, замоченная на ольхе; 9 - Колбаса Докторская по-черкизовски; 10 - Колбаса Докторская охлажденная; 11 - Сосиски куриные без сои.

Таким образом, исследованиями установлены факты фальсификации, когда на мясные продукты, содержащие растительные ингредиенты, представляются документы, в которых декларируется их отсутствие. Это в рав- ной мере касается как отечественной, так и импортной продукции и требует усиления госсанэпиднадзора за продукцией, в том числе, содержащей ГМО, и ее этикетированием.

\section{БИБЛИОГРАФИЯ}

Госсанэпиднадзор за безопасностью продукции, полученной с использованием генно-инженерно-модифицированных организмов (ГМО) растительного происхождения. Методы лабораторного контроля: Учебно-методическое пособие. М. / Медицина для всех: 2007. - 128 с.
ГОСТ Р 52723-2007 «Продукты пищевые и корма. Экспресс-метод определения сырьевого состава (молекулярный)». М.: Стандартинформ, 2007.

Минаев, М. Ю. Методы ПЦР для определения сырьевых компонентов в готовой продукции / М. Ю. Минаев, Б. А. Лиси- 
цын, Т. А. Фомина// Мясная индустрия. - 2008. - №6. - C. $36-37$.

Рогов, И. А. Функциональные свойства соевых белков, полученных из генетически модифицированных источников / И. А. Рогов, Е. Н. Логинова, Н. В. Гурова, Н. Г. Кроха, И. А. Попело, В. В. Сучков// Мясная индустрия. - 2004. - №1. - С. 29 -30 .

Серегин, И. Г. Полимеразная цепная реакция - современный метод выявления фальсификации мясного сырья и продуктов / И. Г. Серегин, А. Ф. Валихов// Мясная индустрия. -2004 - №2 - С. $37-41$.

Хвыля, С. И. Мясная промышленность России: проблемы фальсификации. Ч.1 / С. И Хвыля, Р. В. Паршенкова// Мясной бизнес. - 2006. - №8. - С. 30 - 32.
Хвыля, С. И. Практическое применение гистологического метода в целях идентификации мясных продуктов / С. И. Хвыля, Л. А, Доноскова, Н. В. Менухов// Мясная индустрия. - 2006. - №12. - С. $12-14$.

Шалимова, О. А. Генетически модифицированные белковые компоненты растительного происхождения: применение в перерабатывающей промышленности и риски использования. Рекомендации. / О. А. Шалимова, И. В. Горькова, К. А. Лещуков, Т. А. Штахова. - Орел, 2005. $56 \mathrm{c}$. 